\title{
SOFT SKILLS MATEMATIS MAHASISWA CALON GURU MATEMATIKA
}

\author{
Yudi Darma ${ }^{1}$, Muhamad Firdaus ${ }^{2}$, Wandra Irvandi ${ }^{3}$ \\ ${ }^{1,2,3}$ Pendidikan Matematika IKIP PGRI Pontianak, \\ Jalan Ampera Pontianak \\ 'e-mail: yudidarma@ikippgriptk.ac.id
}

\begin{abstract}
Abstrak
Penelitian bertujuan untuk mengetahui soft skills matematis mahasiswa calon guru matematika yang meliputi kebiasaan berpikir cerdas, keaktifan, minat, motivasi, resiliensi matematik, konsep diri, kepercayaan diri, kemampuan diri, dan penghargaan diri. Populasi penelitian sebanyak 112 orang. Sampel penelitian sebanyak 30 orang yang dipilih dengan purposive sampling. Alat pengumpulan data menggunakan angket. Teknik analisis data menggunakan analisis deskriptif. Hasil penelitian menunjukkan bahwa soft skills matematis mahasiswa pada kategori baik dengan rincian: konsep diri pada kategori sangat baik; kebiasaan berpikir cerdas, keaktifan, minat, motivasi, serta kepercayaan diri mahasiswa pada kategori baik; serta resiliensi matematik, kemampuan diri, dan penghargaan diri mahasiswa pada kategori cukup.
\end{abstract}

Kata Kunci: soft skills matematis, mahasiswa calon guru matematika, analisis deskriptif.

\begin{abstract}
This research aimed to determine the mathematical soft skills of the student mathematics teacher candidates which include habits of mind, activeness, interests, motivation, mathematical resilience, self-concept, self-confidence, self-efficacy, and self-esteem. The population was 112 people. The sample was 30 people selected by purposive sampling. The data collection tool used a questionnaire. The data analysis technique used descriptive analysis. The results showed that the students' mathematical soft skills were in a good category with details: self-concept in the very good category; smart thinking habits, activeness, interest, motivation, and selfconfidence of students in the good category; and mathematical resilience, self-ability, and self-esteem of students in the sufficient category.
\end{abstract}

Keywords: mathematical soft skills, the student mathematics teacher candidates, descriptive analysis.

\section{PENDAHULUAN}

Keberhasilan seseorang tidak hanya ditentukan oleh kemampuan teknis dan pengetahuan saja, namun juga ditentukan oleh keterampilan mengelola diri dan hubungannya dengan orang lain (Muqowim, 2012). Pengetahuan, kemampuan teknis, dan pengelolaan diri berkaitan dengan hard skills dan soft skills. Sumber daya manusia yang berkualitas memerlukan kemampuan yang harus dimiliki yaitu kemampuan hard skills dan juga kemampuan soft skills. Menurut hasil penelitian psikologi sosial menunjukkan bahwa orang yang sukses di dunia ditentukan oleh 
peranan ilmu sebesar $18 \%$, sementara $82 \%$ ditentukan oleh keterampilan emosional, soft skills, dan sejenisnya (Elfindri, dkk., 2010).

Soft skills merupakan istilah untuk menggambarkan pengembangan kecerdasan emosional seseorang berupa kumpulan karakter kepribadian, kepekaan sosial, komunikasi, bahasa, kebiasaan pribadi, keramahan, dan optimisme yang menjadi ciri hubungan dengan orang lain. Termasuk keterampilan dalam berhubungan dengan orang lain (interpersonal skills) dan keterampilan dalam memanajemen dirinya sendiri (intrapersonal skills) sehingga mampu melakukan produktivitas kerja yang maksimal. Sedangkan hard skills yaitu penguasaan ilmu pengetahuan, keterampilan teknis, dan teknologi yang berhubungan dengan ilmu yang dimiliki oleh seseorang (Elfindri, dkk., 2010). Soft skills yang dimaksud yaitu jenis-jenis soft skills matematis yang terdiri dari: disposisi matematis, kemandirian belajar (self-regulated learning), self-efficacy, self-esteem, selfconcept, self-confidence, kebiasaan berpikir cerdas (habits of mind), pendidikan nilai, budaya, dan karakter serta pandangan mahasiswa dalam pembelajaran matematika (Sumarmo, 2015).

Soft skills memiliki peran yang sangat penting dalam membentuk karakter mahasiswa (Darma, dkk., 2020; 2019; 2018; 2016; 2014). Strategi pembelajaran perlu mengoptimalkan interaksi guru dengan mahasiswa maupun mahasiswa dengan mahasiswa. Guru dan mahasiswa harus mampu menciptakan suasana lingkungan yang sehat, kondusif, produktif, dan memperbanyak interaksi banyak arah. Peran dari kreativitas guru untuk mendorong mahasiswa agar dapat terlibat aktif baik secara fisik, sosial, mental, maupun emosional sangat diperlukan untuk membentuk sikap mandiri di dunia kerja dan lingkungan masyarakat.

Mahasiswa tidak hanya menguasai ilmu pengetahuan, teknologi atau kesenian pada bidang tertentu, tetapi juga perlu menguasai keterampilan tambahan, seperti kemampuan berkomunikasi secara efektif, kemampuan berpikir logis, kemampuan bekerja sama, dan kemampuan belajar (Siswati, 2019). Artinya, mahasiswa perlu memiliki kemampuan soft skills yang baik. Namun kenyataannya, praktik pendidikan di Indonesia cenderung memberikan porsi lebih hanya pada kemampuan pengetahuan dan keterampilan saja, yaitu hanya 
berorientasi pada pembelajaran hard skills. Realitas pembelajaran yang dilakukan oleh tenaga pendidik juga cenderung ingin cepat menyelesaikan materi pelajaran, tanpa memberikan perhatian pada peningkatan kreativitas mahasiswa, sikap kerja mahasiswa, serta kurang memberikan kebebasan pada mahasiswa dalam mengungkapkan ide atau gagasan baru, serta belum optimal menumbuhkan komunikasi antar-teman dalam kelompok ketika menyelesaikan suatu masalah.

Rendahnya kemampuan soft skills mahasiswa merupakan masalah penting dalam Pendidikan Matematika. Hal tersebut diduga karena faktor model pembelajaran kurang menyenangkan, kurang partisipasi mahasiswa dalam pembelajaran, serta lingkungan belajar yang belum kondusif. Diperlukan model pembelajaran matematika yang tepat sehingga dapat meningkatkan kemampuan soft skills mahasiswa tersebut. Hasil penelitian yang terkait dengan soft skills peserta didik yaitu terdapat pengaruh kemandirian belajar yang kuat tehadap kemampuan pemecahan masalah matematika sebesar 72,25\% (Darma, dkk., 2016). Kemandirian belajar adalah salah satu bagian soft skills yang harus dimiliki oleh mahasiswa selain kemampuan berkomunikasi dan keterampilan emotional quotient (EQ). Tidak sedikit kegagalan peserta didik di sekolah, masyarakat, dan tempat kerja diakibatkan rendahnya keterampilan dalam berkomunikasi, termasuk keterampilan EQ yang terkait logika dan bahasa dalam bagian otak berpikir. Oleh karenanya diperlukan banyak latihan agar peserta didik terlatih dalam mencari solusi-solusi terhadap masalah yang dihadapi.

Berdasarkan permasalahan yang telah diuraikan, maka perlu untuk mengetahui lebih jauh capaian soft skills mahasiswa dalam proses perkuliahan bagi calon-calon guru Pendidikan Matematika. Sehingga diharapkan dapat menjadi evaluasi atau pandangan bersama untuk mengoptimalkan soft skills dalam proses perkuliahan.

\section{METODE}

Penelitian termasuk penelitian deskriptif yang bertujuan untuk mendeskripsikan soft skills matematis mahasiswa calon guru matematika di lingkungan Program Studi Pendidikan Matematika agar dapat dijadikan acuan 
sebagai evaluasi dalam proses pembelajaran. Adapun soft skills matematis yang dimaksud yaitu kebiasaan berpikir cerdas (habits of mind), keaktifan belajar, minat belajar, motivasi, resiliensi matematik, konsep diri (self-concept), kepercayaan diri (self-confidence), kemampuan diri (self-efficacy), dan penghargaan diri (selfesteem) (Sumarmo, 2015).

Habits of mind terdiri dari 32 item yang dijabarkan dari indikator: bertahan dan pantang menyerah atau tidak mudah frustasi; mengatur kata hati; berempati terhadap perasaan orang lain; berpikir luwes; reflektif; percaya diri; terbuka; berpikir metakognitif; bekerja teliti dan tepat; mencapai standar yang tinggi; bertanya; mengajukan masalah secara efektif disertai data pendukung; memanfaatkan pengalaman lama; beranalogi, berpikir, serta berkomunikasi secara jelas dan tepat; memanfaatkan indera dengan tajam; berpikir intuitif; membuat perkiraan solusi; mencipta, berkhayal, dan berinovasi; bersemangat dalam merespons; berani bertanggung jawab dan menghadapi resiko; humoris dan berpikir saling bergantungan; serta belajar berkelanjutan (Hendriana, dkk., 2015; Costa, 2001; Jacobbe dan Millman, 2009).

Keaktifan belajar terdiri dari 18 item yang dijabarkan dari indikator: memperhatikan penjelasan guru; memahami masalah yang diberikan oleh guru; aktif bertanya dan menjawab pertanyaan; bekerja sama dalam kelompok; kemampuan mengemukakan pendapat; memberi kesempatan berpendapat kepada teman dalam kelompok; serta mempresentasikan hasil kerja kelompok (Sardiman, 2005; Hamalik, 2003). Minat belajar terdiri dari 18 item yang dijabarkan dari indikator: perasaan yang senang; ketertarikan belajar siswa; keterlibatan siswa dalam belajar; rajin belajar dan mengerjakan tugas matematika; serta tekun, disiplin, dan mempunyai jadwal belajar (Hendriana, dkk., 2017; Brown, 2011).

Motivasi terdiri dari 25 item yang dijabarkan dari indikator: percaya diri dalam menggunakan matematika; fleksibel dalam melakukan kerja matematika; kerelaan meninggalkan kewajiban atau tugas lain; ketekunan dalam mengerjakan matematika; dapat mempertahankan pendapat; serta gigih dan ulet dalam mengerjakan tugas-tugas matematika (Kaniawaty, 2016). Resiliensi matematik terdiri dari 28 item yang dijabarkan dari indikator: sikap tekun; yakin atau percaya 
diri; bekerja keras; tidak mudah menyerah menghadapi masalah; kegagalan dan ketidakpastian; berkeinginan bersosialisasi; mudah memberi bantuan; berdiskusi dengan sebayanya dan beradaptasi dengan lingkungannya; menunjukkan rasa ingin tahu; merefleksi, meneliti, dan memanfaatkan beragam sumber; memiliki kemampuan berbahasa; serta mengontrol diri dan sadar akan perasaannya (Hendriana, dkk., 2015; Johnston-Wilder dan Lee, 2010).

Konsep diri terdiri dari 32 item yang dijabarkan dari indikator: menunjukkan kemauan, keberanian, kegigihan, kesungguhan, keseriusan, dan ketertarikan belajar matematika; percaya diri akan kemampuan diri dan berhasil; mengenali kekuatan dan kelemahan diri sendiri dalam matematika; menunjukkan kerja sama dan toleran kepada orang lain; menghargai pendapat orang lain dan sendiri; dapat memaafkan kesalahan orang lain dan sendiri; menunjukkan kemampuan berkomunikasi dan tahu menempatkan diri; serta pandangan, manfaat, kesukaan terhadap bidang studi dan belajar matematika (Sumarmo, 2015). Kepercayaan diri terdiri dari 42 item yang dijabarkan dari indikator: percaya pada kemampuan sendiri; tidak cemas, merasa bebas, dan bertanggung jawab atas perbuatannya; bertindak mandiri dalam mengambil keputusan; berani mengungkapkan pendapat dan memiliki dorongan untuk berprestasi; serta mengenal kelebihan dan kekurangan diri sendiri (Hendriana, dkk., 2015).

Kemampuan diri terdiri dari 28 item yang dijabarkan dari indikator: mampu mengatasi masalah yang dihadapi; yakin akan keberhasilan dirinya; berani menghadapi tantangan; berani menggambil resiko; menyadari kekuatan dan kelemahan dirinya; mampu berinteraksi dengan orang; serta tangguh atau tidak mudah menyerah (Sumarmo, 2015). Penghargaan diri terdiri dari 27 item yang dijabarkan dari indikator: rasa percaya diri terhadap kemampuannya; yakin terhadap dirinya dalam berkomunikasi; yakin terhadap kekuatan dan kelemahan dirinya; rasa bangga terhadap hasil yang dicapainya; serta percaya diri bahwa dirinya dibutuhkan orang lain (Hendriana, dkk., 2015).

Populasi penelitian yaitu mahasiswa calon guru Program Studi Pendidikan Matematika IKIP PGRI Pontianak semester V yang berjumlah 112 mahasiswa. Sampel penelitian sebanyak 30 mahasiswa yang dipilih menggunakan teknik 
purposive sampling. Teknik pengumpul data menggunakan teknik komunikasi tidak langsung. Alat pengumpul data berupa angket yang diberikan pada saat proses pembelajaran berlangsung. Angket yang digunakan merupakan adaptasi dari angket penelitian Hendriana, dkk. (2015) yang telah tervalidasi dan reliabel. Teknik analisis data menggunakan analisis deskriptif yang dimulai dari tahap konversi berdasarkan skor dan item setiap pernyataan yang telah dikembangkan, kemudian dihitung menggunakan rerata yang selanjutnya diinterpretasi dengan kriteria sesuai dengan kategorisasi variabel soft skills pada Tabel 1 (dikembangkan dari interval skala Likert 1-4).

Tabel 1 Kategori Atribut Soft Skills

\begin{tabular}{cc}
\hline Kategori Soft Skills & Interval Rerata Capaian \\
\hline Kurang & $0-2,50$ \\
Cukup & $2,51-3,00$ \\
Baik & $3,01-3,50$ \\
Sangat Baik & $3,51-4,00$ \\
\hline
\end{tabular}

\section{HASIL DAN PEMBAHASAN}

Hasil analisis mengenai soft skills mahasiswa Program Studi Pendidikan Matematika IKIP PGRI Pontianak berada pada kategori baik dengan rerata 3,03 dari 9 soft skills yang diukur.

Tabel 2 Soft Skills Matematis Mahasiswa

\begin{tabular}{ccc}
\hline Aspek Soft Skills & Rerata & Kategori \\
\hline Habits of mind & 3,03 & Baik \\
Keaktifan & 3,02 & Baik \\
Minat & 3,14 & Baik \\
Motivasi & 3,27 & Baik \\
Resiliensi & 2,78 & Cukup \\
Self-concept & 3,53 & Sangat Baik \\
Self-confidence & 3,37 & Baik \\
Self-efficacy & 2,86 & Cukup \\
Self-esteem & 2,83 & Cukup \\
\hline Rerata & $\mathbf{3 , 0 9}$ & Baik \\
\hline
\end{tabular}

Hasil penelitian mengenai kemampuan soft skills matematis mahasiswa yang meliputi kebiasaan berpikir cerdas (habits of mind), keaktifan belajar 
matematis, minat belajar, motivasi, resiliensi matematik, konsep diri (self-concept), kepercayaan diri (self-confidence), kemampuan diri (self-efficacy), dan penghargaan diri (self-esteem) diuraikan sebagai berikut.

\section{Kebiasaan Berpikir Cerdas (Habits of Mind) Mahasiswa}

Aspek kebiasaan berpikir cerdas (habits of mind) diperoleh rerata sebesar 3,03 dengan kategori baik dengan rincian 17 butir dengan kategori baik, 14 butir dengan kategori cukup, dan 1 butir dengan kategori kurang.

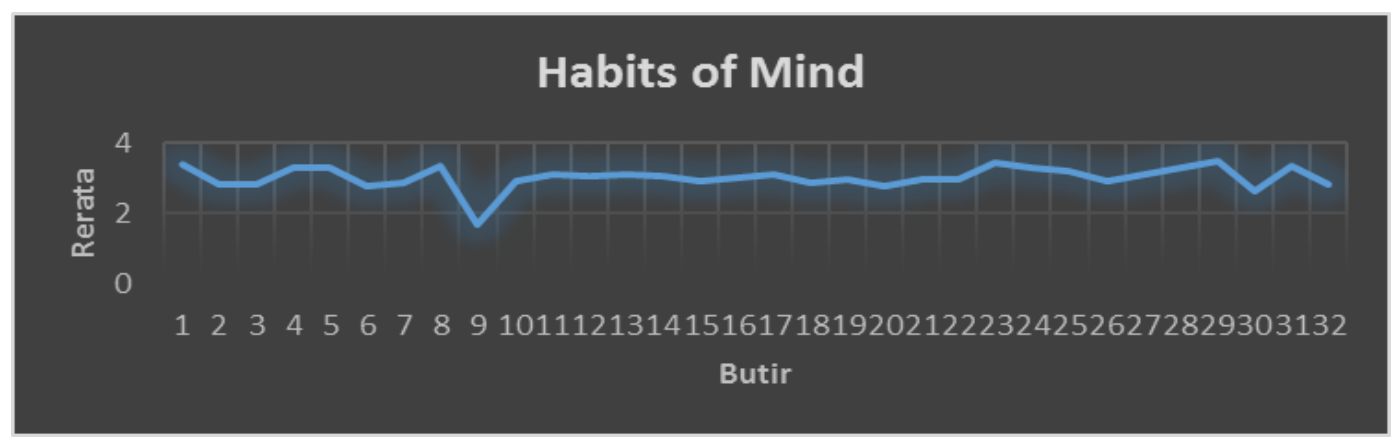

\section{Gambar 1 Hasil Habits of Mind Mahasiswa}

Gambar 1 menunjukkan bahwa pada indikator berpikir metakognitif; memanfaatkan pengalaman lama; beranalogi; memanfaatkan indera dengan tajam, berpikir intuitif, dan membuat perkiraan solusi; serta mencipta, berkhayal, dan berinovasi dengan kategori cukup. Sedangkan indikator berpikir metakognitif dengan kategori cukup, khususnya yang berkaitan dengan memikirkan cara pemecahan masalah. Aspek metakognitif merupakan bagian dari kemampuan dalam memecahkan masalah, sehingga hal tersebut perlu menjadi perhatian bagi tenaga pendidik agar dapat mengoptimalkan kemampuan berpikir metakognitif, karena metakognitif menekankan pada pembentukan pengetahuan dan keterampilan oleh siswa (Darma dan Sujadi, 2016). Hasil penelitian mendukung penelitian sebelumnya yang menunjukkan bahwa kebiasaan berpikir cerdas subjek penelitian berada pada kategori baik (Aringga, dkk., 2019; Defitriani, 2019).

\section{Keaktifan Belajar Mahasiswa}

Aspek keaktifan belajar diperoleh rerata sebesar 3,02 dengan kategori baik dengan rincian 1 butir dengan kategori sangat baik, 11 butir dengan kategori baik, 
4 butir dengan kategori cukup, dan 2 butir dengan kategori kurang.

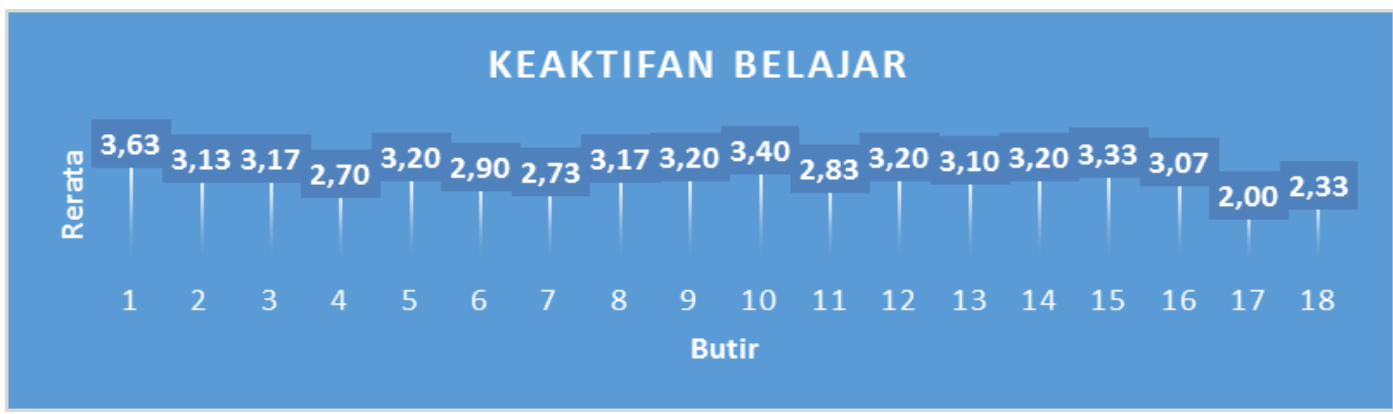

\section{Gambar 2 Hasil Keaktifan Belajar Mahasiswa}

Gambar 2 menunjukkan bahwa pada indikator mempersentasikan hasil kerja kelompok masih dalam kategori kurang. Diketahui bahwa keaktifan belajar mahasiswa calon guru matematika berada pada posisi ambang batas, hal tersebut perlu menjadi perhatian untuk meningkatkan aktivitas belajar mahasiswa. Terutama yang selaras dengan 8 kegiatan aktivitas belajar yang digolongkan oleh Diedrich (Sardiman, 2005; Hamalik, 2003). Hasil penelitian mendukung penelitian sebelumnya yang menunjukkan bahwa keaktifan belajar subjek penelitian berada pada kategori sangat baik (Ario, 2018).

\section{Minat Belajar Mahasiswa}

Aspek minat belajar diperoleh rerata sebesar 3,14 dengan kategori baik dengan rincian 2 butir dengan kategori sangat baik, 10 butir dengan kategori baik, dan 6 butir dengan kategori cukup.

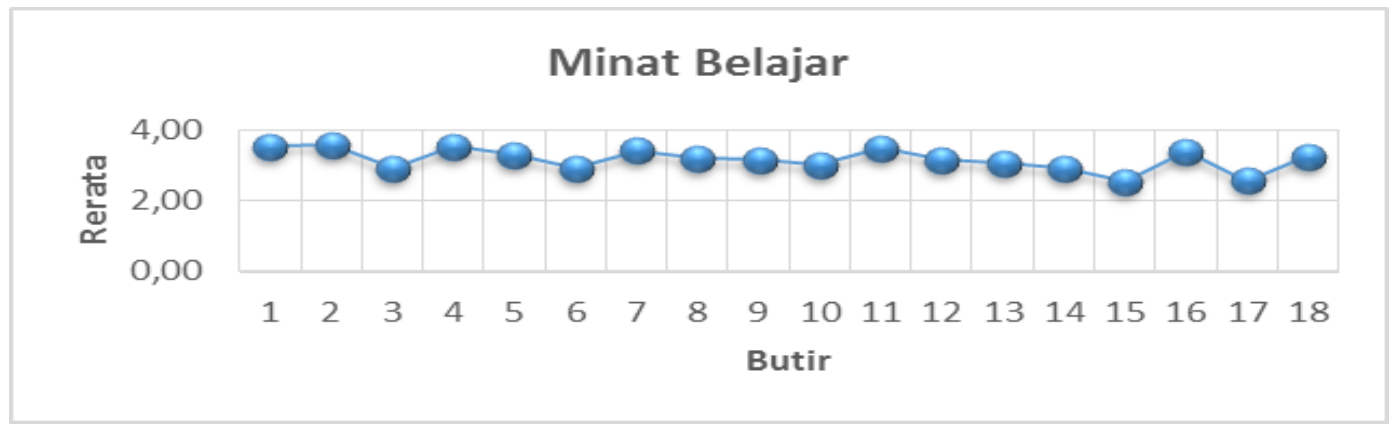

\section{Gambar 3 Hasil Minat Belajar Mahasiswa}

Gambar 3 menunjukkan bahwa pada indikator rajin dalam belajar dan rajin mengerjakan tugas matematika dengan kategori cukup. Hal tersebut tentunya menjadi pekerjaan rumah oleh setiap tenaga pendidik maupun peserta didik, 
karena salah satu keberhasilan seorang tenaga pendidik tidak hanya mampu mentransfer ilmu pengetahuan atau tercapainya kompetensi yang menjadi target, akan tetapi keberhasilannya juga dilihat dari kesadaran peserta didik akan kebutuhan belajar dan bertanggung jawab terhadap tugas yang diberikan. Hasil penelitian mendukung penelitian sebelumnya yang menunjukkan bahwa minat belajar subjek penelitian berada pada kategori sangat baik atau tinggi (Situmorang dan Siahaan, 2019; Hidayat, 2018).

\section{Motivasi Belajar Mahasiswa}

Aspek motivasi diperoleh rerata sebesar 3,27 dengan kategori baik dengan rincian 2 butir dengan kategori sangat baik, 21 butir dengan kategori baik, dan 2 butir dengan kategori cukup.

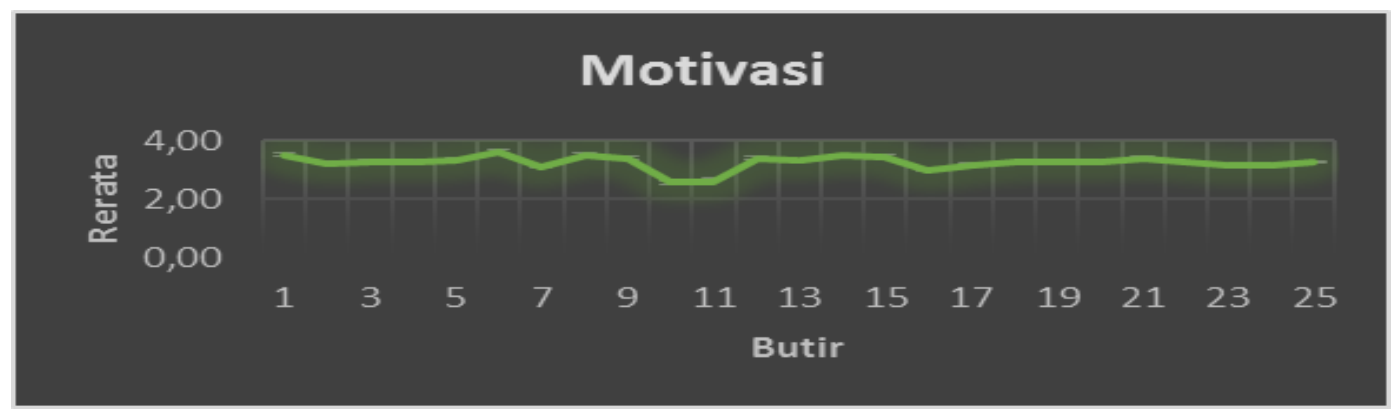

\section{Gambar 4 Hasil Motivasi Belajar Mahasiswa}

Gambar 4 menunjukkan bahwa pada indikator percaya diri dalam menggunakan matematika; fleksibel dalam melakukan kerja matematika; kerelaan meninggalkan kewajiban atau tugas lain; dapat mempertahankan pendapat; serta gigih dan ulet dalam mengerjakan tugas-tugas matematika masuk dalam kategori baik. Namun untuk indikator ketekunan dalam mengerjakan matematika diperoleh dengan kategori cukup, sehingga menjadi penguat bahwa hal-hal yang bersifat ketekunan atau rajin belajar menjadi perhatian bersama untuk dapat diatasi, selaras dengan indikator pada aspek minat belajar. Hasil penelitian mendukung penelitian sebelumnya yang menunjukkan bahwa motivasi belajar subjek penelitian berada pada kategori baik atau tinggi (Yudha, 2018; Alifiani, 2017). 


\section{Resiliensi Matematik Mahasiswa}

Aspek resiliensi matematik diperoleh rerata sebesar 2,78 dengan kategori cukup dengan rincian 3 butir dengan kategori baik, 23 butir dengan kategori cukup, dan 2 butir dengan kategori kurang.

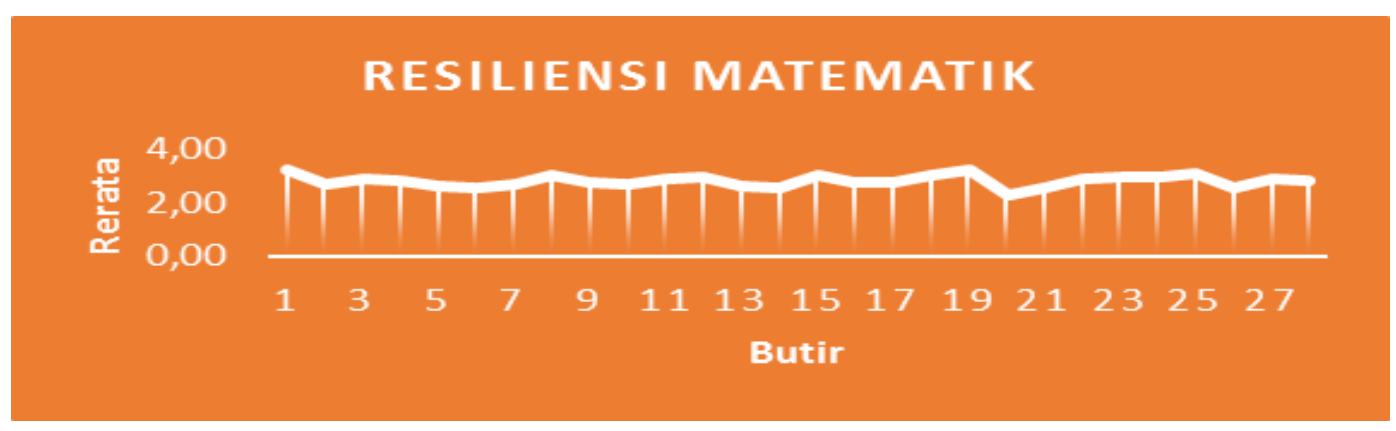

\section{Gambar 5 Hasil Resiliensi Matematik Mahasiswa}

Gambar 5 menunjukkan indikator sikap tekun; yakin atau percaya diri; bekerja keras; tidak mudah menyerah menghadapi masalah; kegagalan dan ketidakpastian; berkeinginan bersosialisasi; mudah memberi bantuan; berdiskusi dengan sebayanya dan beradaptasi dengan lingkungannya; menunjukkan rasa ingin tahu, merefleksi, meneliti, memanfaatkan beragam sumber; serta memiliki kemampuan berbahasa, mengontrol diri, dan sadar akan perasaannya. Khusus pada poin terakhir berada pada kategori kurang. Hal tersebut berarti bahwa aspek resiliensi matematik harus menjadi salah satu fokus utama dalam penelitian lain atau sejenisnya berkenaan dengan perbaikan kualitas pembelajaran matematika. Hasil penelitian mendukung penelitian sebelumnya yang menunjukkan bahwa resiliensi matematik subjek penelitian berada pada kategori cukup atau kurang (Rahmatiya dan Miatun, 2020; Ariyanto, dkk., 2018).

\section{Konsep Diri (Self-Concept) Mahasiswa}

Aspek konsep diri (self-concept) diperoleh rerata sebesar 3,53 dengan kategori sangat baik dengan rincian 21 butir dengan kategori sangat baik dan 11 butir dengan kategori baik. Gambar 6 menunjukkan bahwa pada indikator berpikir yaitu menunjukkan kemauan, keberanian, kegigihan, kesungguhan, keseriusan, ketertarikan belajar matematika; percaya diri akan kemampuan dan berhasil, mengenali kekuatan dan kelemahan diri sendiri dalam matematika; serta 
menunjukkan kemampuan berkomunikasi dan tahu menempatkan diri yang berada pada kategori cukup.

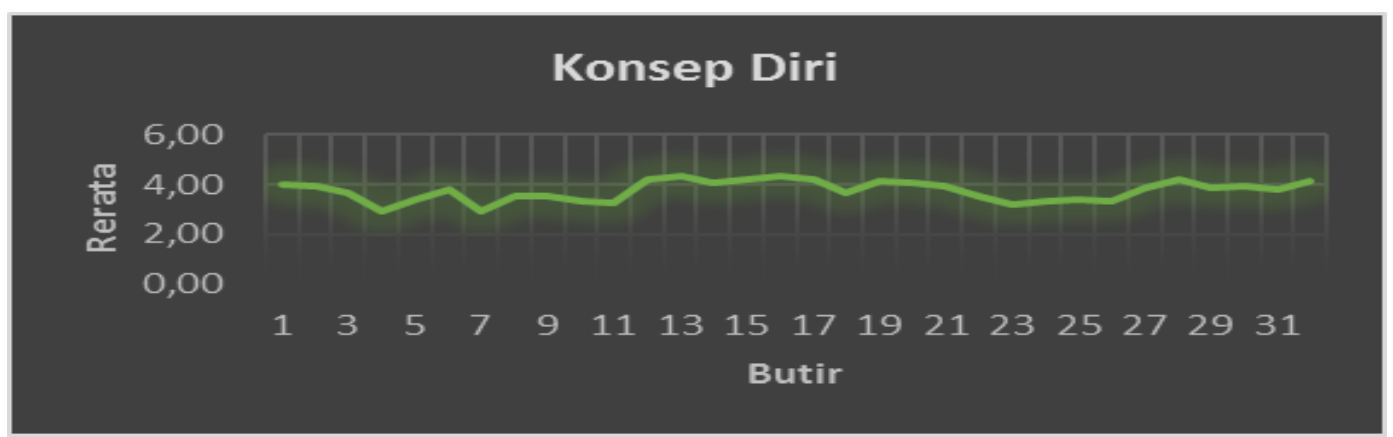

\section{Gambar 6 Hasil Konsep Diri Mahasiswa}

Hasil penelitian mendukung penelitian sebelumnya yang menunjukkan bahwa self-concept subjek penelitian berada pada kategori tinggi (Sadikin dan Kaharuddin, 2019).

\section{Kepercayaan Diri (Self-Confidence) Mahasiswa}

Aspek kepercayaan diri (self-confidence) diperoleh rerata sebesar 3,37 dengan kategori baik dengan rincian 22 butir dengan kategori baik dan 20 butir dengan kategori cukup.

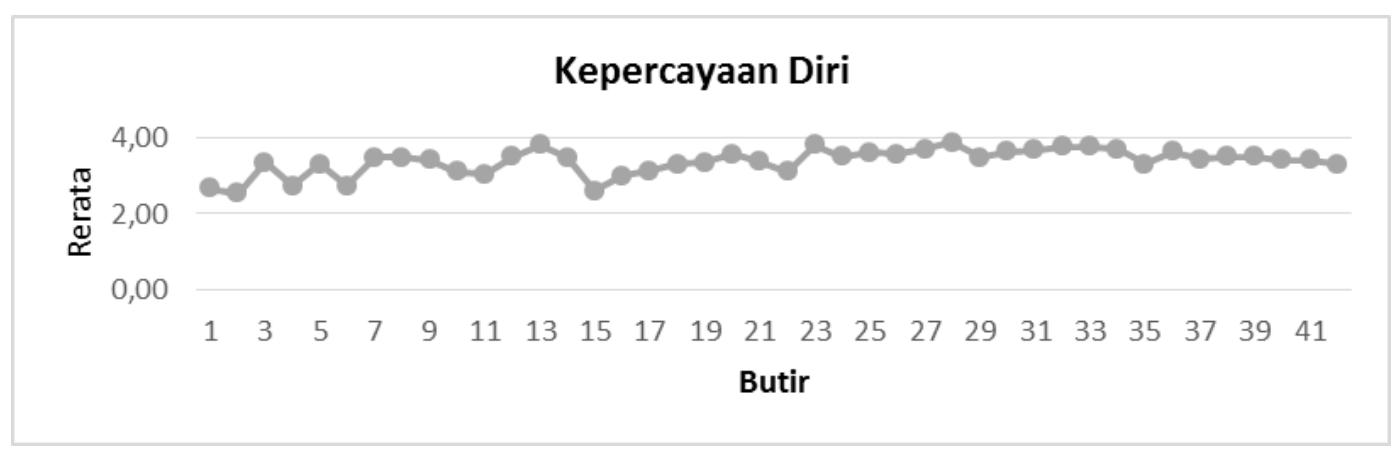

\section{Gambar 7 Hasil Kepercayaan Diri Mahasiswa}

Gambar 7 menunjukkan bahwa pada indikator percaya pada kemampuan sendiri, tidak cemas; bertindak mandiri dalam mengambil keputusan berada kategori cukup. Masing-masing indikator mahasiswa memiliki kepercayaan diri yang cukup lemah sehingga turut memberikan dampak yang tidak baik pada kemandirian dan kepercayaan dalam mengambil keputusan. Hasil penelitian mendukung penelitian sebelumnya yang menunjukkan bahwa self-confidence 
subjek penelitian berada pada kategori baik (Sopia, 2016; Aminah, 2014).

\section{Kemampuan Diri (Self-Efficacy) Mahasiswa}

Aspek kemampuan diri (self-efficacy) diperoleh rerata sebesar 2,86 dengan kategori cukup dengan rincian 8 butir dengan kategori baik, 18 butir dengan kategori cukup, dan 2 butir dengan kategori kurang.

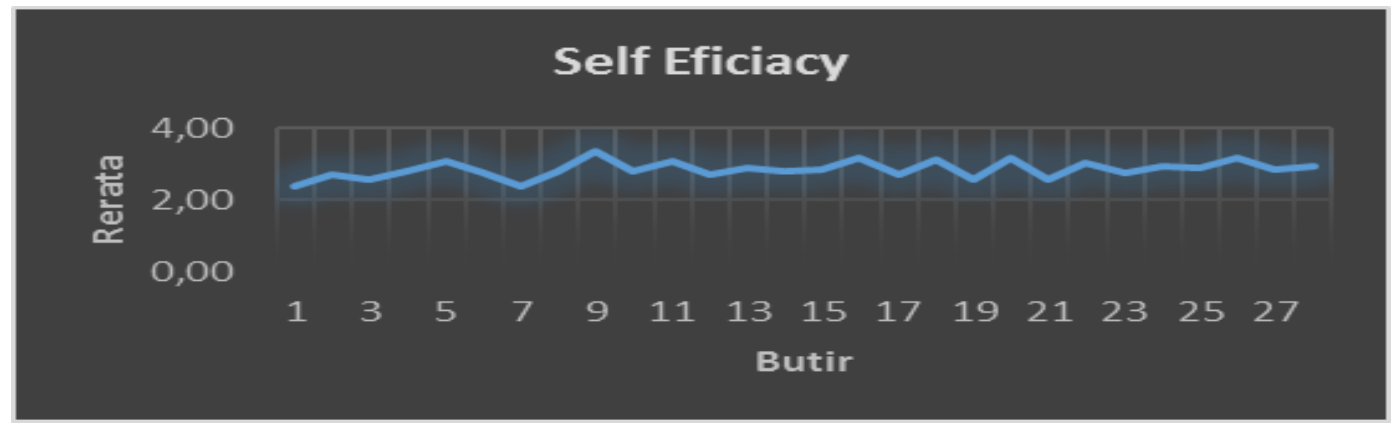

Gambar 8 Hasil Kemampuan Diri Mahasiswa

Gambar 8 menunjukkan bahwa pada indikator mampu mengatasi masalah yang dihadapi; yakin akan keberhasilan dirinya; berani menggambil resiko; menyadari kekuatan dan kelemahan dirinya; mampu berinteraksi dengan orang; dan tangguh atau tidak mudah menyerah yang berada pada kategori cukup. Hasil penelitian mendukung penelitian sebelumnya yang menunjukkan bahwa selfefficacy subjek penelitian berada pada kategori sedang (Sanhadi, 2015).

\section{Penghargaan Diri (Self-Esteem) Mahasiswa}

Aspek penghargaan diri (self-esteem) diperoleh rerata sebesar 2,83 dengan kategori cukup dengan rincian 6 butir dengan kategori baik, 20 butir dengan kategori cukup, dan 1 butir dengan kategori kurang.

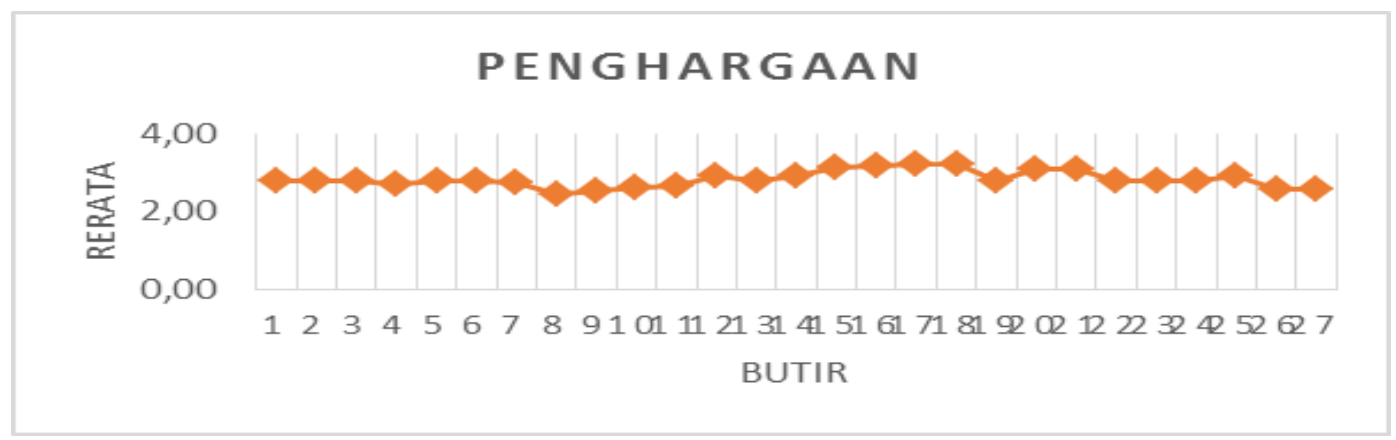

Gambar 9 Hasil Penghargaan Diri Mahasiswa 
Gambar 9 menunjukkan bahwa pada indikator kemampuan untuk yakin terhadap dirinya dalam berkomunikasi; yakin terhadap kekuatan dan kelemahan dirinya; dan percaya diri bahwa dirinya dibutuhkan orang lain dengan kategori cukup. Hasil penelitian mendukung penelitian sebelumnya yang menunjukkan bahwa self-esteem subjek penelitian berada pada kategori cukup atau sedang (Mahani, dkk., 2019; Pamungkas, dkk., 2017).

\section{SIMPULAN}

Berdasarkan hasil penelitian, soft skills matematis calon guru Pendidikan matematika berada pada kategori baik. Adapun hasil aspek-aspek soft skills sebagai berikut: konsep diri mahasiswa calon guru Pendidikan Matematika pada kategori sangat baik; kebiasaan berpikir cerdas, keaktifan, minat, motivasi serta kepercayaan diri mahasiswa calon guru Pendidikan Matematika berada pada kategori baik; serta resiliensi matematika, kemampuan diri dan penghargaan diri mahasiswa calon guru Pendidikan Matematika berada pada kategori cukup.

\section{DAFTAR PUSTAKA}

Alifiani. 2017. Penerapan Model Pembelajaran NHT-TGT untuk Meningkatkan Motivasi dan Pemahaman Konsep Materi Matematika SMA. Jurnal Riset Pendidikan Matematika, 4(1): 11-20.

Aminah, N. 2014. Analisis Kemampuan Pedagogik dan Self Confidence Calon Guru Matematika dalam Menghadapi Praktek Pengalaman Lapangan. Jurnal Euclid, 1(1): 55-59.

Aringga, D., Shodiqin, A., \& Albab, I. U. 2019. Penelusuran Kebiasaan Berpikir (Habits of Mind) Matematis Siswa dalam Menyelesaiakan Soal Cerita Bilangan Pecahan Ditinjau dari Gaya Kognitif. Thinking Skills and Creativity Journal, 2(2): 121-129.

Ario, M. 2018. Implementasi Lesson Study untuk Menumbuhkan Keaktifan Belajar dan Kerjasama Mahasiswa. Jurnal Absis: Jurnal Pendidikan Matematika dan Matematika, 1(1): 1-11.

Ariyanto, L., Tsalatsa, A. N., \& Prayitno, M. 2018. Analisis Free Orientation dan Resilience Mahasiswa pada Mata Kuliah Pengembangan Media Pembelajaran Matematika. JIPMat (Jurnal Ilmiah Pendidikan Matematika), 3(1): 29-36.

Brown, G. W. 2011. Student Centered Learning in Higher Education. International Journal of Teaching in Higher Education, 23(3): 93-97.

Costa, A. L. 2001. Habits of Mind dalam A.L. Costa (Ed.). 2001. Developing Minds. A Resource Book for Teaching Thinking. 3rd Edition. Virginia USA: 
Assosiation for Supervision and Curriculum Development.

Darma, Y., Suratman, D., \& Susiaty, U. D. 2020. Balance of Soft Skills and Hard Skills: Development of Subject Specific Pedagogic Based on Heuristic Strategy with Character Contents in Learning. AIP Conference Proceedings. AIP Publishing LLC (Vol. 2268, No. 1, p. 030003).

Darma, Y., Suratman, D., Yani, A., \& Susiaty, U. D. 2019. Improving ProblemSolving Ability And Character In Subject-Specific Pedagogic With Heuristic Strategy. Journal of Education, Teaching, and Learning, 14(2): 169-178.

Darma, Y., Susiaty, U. D., \& Fitriawan, D. 2018. Pendidikan Karakter dalam Pembelajaran pada Mahasiswa Calon Guru Matematika. SAP (Susunan Artikel Pendidikan), 3(2): 110-115.

Darma, Y. \& Sujadi, I. 2016. Strategi Heuristik dengan Pendekatan Metakognitif dan Investigasi Terhadap Kemampuan Pemecahan Masalah Matematis Ditinjau dari Kreativitas Siswa Madrasah Aliyah. Jurnal Pendidikan MIPA, 15(2): 110-119.

Darma, Y., Firdaus, M., \& Haryadi, R. 2016. Hubungan Kemandirian Belajar terhadap Kemampuan Pemecahan Masalah Matematis Mahasiswa Calon Guru Matematika. Edukasi: Jurnal Pendidikan, 14(1): 169-178.

Defitriani, E. 2019. Profil Habits of Mind Mahasiswa Program Studi Pendidikan Matematika FKIP Universitas Batanghari Jambi. PHI: Jurnal Pendidikan Matematika, 3(2): 57-64.

Elfindri, Rumengan, J., Wello, M. B., Tobing, P., Yanti, F., Eriyani, Z. E., Indra, R. 2010. Peningkatan Soft Skills Siswa SMP melalui Pembelajaran Generatif Soft Skills untuk Pendidik. Jakarta: Baduose Media.

Hamalik. 2003. Perencanaan Pengajaran Berdasarkan Pendekatan Sistem. Jakarta: PT. Bumi Aksara.

Hendriana, Rohaeti, \& Sumarmo. 2017. Hard Skills dan Soft Skills Matematik Siswa. Bandung: PT Refika Aditama.

Hendriana, Rohaeti, \& Sumarmo. 2015. Meningkatkan Beragam Hard Skill dan Soft Skill Matematika Siswa Sekolah Menengah melalui Beragam Pendekatan Pembelajaran. Laporan Penelitian Hibah Pascasarjana DIKTI tahun kedua 2015: tidak dipublikasikan.

Hidayat, P. W. 2018. Analisis Profil Minat Belajar dan Kemampuan Pemahaman Konsep Dasar Matematika SD pada Mahasiswa S1 PGSD STKIP Muhammadiyah Muara Bungo. Lemma: Letters of Mathematics Education, 4(2): 62-74.

Jacobbe, T. \& Millman, R. S. 2009. Mathematical Habits of the Mind for Preservice Teachers. School Science and Mathematics, 109(5): 298-302.

Johnston-Wilder, S. \& Lee, C. 2010. Mathematical Resilience. Mathematics Teaching, 218(5): 28-41.

Kaniawaty, R. 2016. Mengembangkan Kemampuan Berpikir Kritis dan Kreatif Matematik serta Motivasi Siswa SMP di Kabupaten Bandung Barat Melalui Metode Tutor Sebaya. Tesis pada Pascasarjana STKIP Siliwangi Bandung: tidak dipublikasikan.

Mahani, I., Budiyono, \& Pratiwi, H. 2019. The Effect of Self-Esteem on Students' Mathematical Communication Skills. Al-Jabar: Jurnal Pendidikan 
Matematika, 10(1): 79-86.

Muqowim. 2012. Pengembangan Soft Skills Guru. Yogyakarta: Insan Madani.

Pamungkas, A. S., Setiani, Y., \& Pujiastuti, H. 2017. Peranan Pengetahuan Awal dan Self Esteem Matematis terhadap Kemampuan Berpikir Logis Mahasiswa. Kreano, Jurnal Matematika Kreatif-Inovatif, 8(1): 61-68.

Rahmatiya, R. \& Miatun, A. 2020. Analisis Kemampuan Pemecahan Masalah Matematis Ditinjau dari Resiliensi Matematis Siswa SMP. Teorema: Teori dan Riset Matematika, 5(2): 187-202.

Sadikin \& Kaharuddin, A. 2019. Identifikasi Kemampuan Komunikasi Matematika Ditinjau dari Self-Concept Matematis dan Gender. Prosiding Seminar Nasional Pendidikan Matematika II Tahun 2019, Kendari: 31 Agustus 2019. Hal: 190-198.

Sanhadi, K. C. D. 2015. Pengaruh Kemampuan Penalaran dan Self-Efficacy terhadap Hasil Belajar Matematika Siswa Kelas VIII. Prosiding Seminar Nasional Matematika dan Pendidikan Matematika UNY 2015, Yogyakarta: 14 November 2015. Hal: 341-350.

Sardiman, A. M. 2005. Interaksi dan Motivasi Belajar Mengajar. Jakarta: Rajawali Press.

Siswati, S. 2019. Pengembangan Soft Skills dalam Kurikulum untuk Menghadapi Revolusi Industri 4.0. Edukasi: Jurnal Pendidikan, 17(2): 264-273.

Situmorang, A. S. \& Siahaan, F. B. 2019. Desain Model Pencapaian Konsep terhadap Minat Belajar Mahasiswa FKIP UHN. Jurnal Penelitian Bidang Pendidikan, 25(1): 55-61.

Sopia, H. F. 2016. Kepercayaan Diri Mahasiswa PGSD Universitas Muhammadiyah Tangerang pada Mata Kuliah Konsep Dasar Matematika. Jurnal Pendidikan Sekolah Dasar, 2(2): 117-124.

Sumarmo, U. 2015. Pengembangan dan Contoh Butir, Skala Nilai, Karakter, Budaya dan Aspek Afektif lain dalam Pembelajaran Matematika dalam dosen.ikipsiliwangi.ac.id/Utari-Sumarmo. Diakses 6 Juni 2020.

Yudha, C. B. 2018. Peningkatan Motivasi Belajar Mahasiswa pada Mata Kuliah Konsep Dasar Matematika melalui Pendekatan Contextual Teaching and Learning. Jurnal Pendidikan Dasar, 9(1): 12-27. 